\title{
Physical and Chemical Properties of Soybean-growing Soils in Different Agro-ecological Zones of Marathwada Region
}

\author{
K. R. Malode ${ }^{1 *}$, V. D. Patil ${ }^{1}$ and S. R. Lakhe ${ }^{2}$ \\ ${ }^{\prime}$ Department of Soil Science and Agricultural Chemistry, Vasantrao Naik Marathwada Krishi Vidyapeeth, \\ Parbhani, 431 402, Maharashtra, India \\ ${ }^{2}$ Department of Soil Science and Agricultural Chemistry, Dr. Panjabrao Deshmukh Krishi Vidyapeeth, \\ Akola, 444 104, Maharashtra, India
}

\begin{abstract}
Horizon-wise soil samples (9 profiles) from Osmanabad, Latur, Beed (Drought prone zone) and Nanded, Parbhani (assured rainfall zone) from Marathwada region were collected and analyzed. The sand, silt and clay content ranged from 10.20 to $34.30,17.90$ to 32.20 and 43.70 to $59.30 \%$ respectively. The soils were slightly to moderately alkaline in reaction. The saturated hydraulic conductivity (sHC) ranged from 0.20 to $5.30 \mathrm{~cm} \mathrm{hr}^{1}$ and CEC of soils varied from 33.30 to $67.10 \mathrm{cmol}(\mathrm{p}+) \mathrm{kg}^{-1}$. Majority of surface and sub-surface layers had relatively higher soil organic carbon than underlying ones. The available N, P and $\mathrm{K}$ content ranged from 37.60 to $334.80,1.0$ to 27.10 and 224.90 to $583.80 \mathrm{~kg} \mathrm{ha}^{-1}$ in soils, respectively. The DTPA-Zn found deficient in all the soils.
\end{abstract}

Key words: Physical and chemical properties, agro-ecological zone, soybean

\section{Introduction}

Soybean (Glycine $\max$ L.) is one of the most important legume cum oilseed crop of the world and cheapest source of protein. The drought prone zone and assured rainfall zone of agro-ecological zone- 6 in Marathwada region of Maharashtra is arid and semi-arid part under rainfed farming with erratic rainfall distribution resulting in low productivity of soybean. However, higher productivity of crop could be managed by suitable agro-managements (Hajare et al. 1995) and by illuviating the constraints (Jagdish Prasad and Bradely 1997) and in particular fertility (Karthikeyan et al. 2014). In view of the above, an attempt has been made to characterize the soybean-growing soils to know the soil characteristics and its related constraints so that action plan can be formulated.

\section{Materials and Methods}

Studyarea

Marathwada region $\left(74^{\circ} 40^{\prime}\right.$ to $7015^{\prime} \mathrm{E}, 17^{\circ} 35$ to $20^{\circ} 40^{\prime} \mathrm{N}$ ) with an elevation ranging from 347 to $638 \mathrm{~m}$ above mean sea level (MSL). Osmanabad, Latur and Beed (Drought prone zone) and Nanded, Parbhani (assured rainfall zone) nine profile viz., $\mathrm{P}_{1}(\mathrm{Kej}), \mathrm{P}_{2}$ (Ahmadpur), $\mathrm{P}_{3}$ (Ausa), $\mathrm{P}_{4}$ (Beed), $\mathrm{P}_{5}$ (Govindpur), $\mathrm{P}_{6}$ (Wadgaon), $\mathrm{P}_{7}$ (Dhasadi), $\mathrm{P}_{8}$ (Lohgaon) and $\mathrm{P}_{9}$ (Bharaswada), from Osmanabad, Latur and Beed (Drought prone zone) and Nanded, Parbhani (Assured rainfall zone) were studied and horizon-wise collected for laboratory analysis were selected from Marathwada region. The soil temperature regime was hyperthermic and moisture regime is Ustic.

*Corresponding author: (E-mail: munna.acss@gmail.com) 


\section{Sample collection and analysis}

Particle-size distribution was determined as per the international pipette method, bulk density by clod coating method and hydraulic conductivity by constant head method. The $\mathrm{pH}$ and EC were measured in 1:2.5 soil-water suspension. Available $\mathrm{N}$ was determined by permanganate method (Subbiah and Asija 1956), available phosphorus by Olsen et al. (1954) and available potassium by ammonium acetate extractant (Jackson 1973). Cation exchange capacity (CEC) was determined by $1 \mathrm{NNaOAc}$ at $\mathrm{pH}$ 8.2. Exchangeable $\mathrm{Ca}^{2+}$ was determined by KCI-triethanolamine method followed by EDTA titration and organic carbon by Walkley and Black (1934) method and total carbon by sum of soil inorganic carbon and organic carbon (Anonymous 2001). Calcium carbonate equivalent was determined by acid neutralization method of Black et al. (1965). Available zinc, copper, iron and manganese were extracted by $0.005 M$ DTPA solution (Lindsay and Norvell 1978) and estimated on Atomic absorption spectrophotometer.

\section{Results and Discussion}

\section{Physical and chemical properties of soil}

The partial-size distribution and sand/silt ratio showed inflection in sand, silt and clay content with depth. The sand, silt and clay content ranged from 10.2 to 34.3 and 17.9 to 33.1 per cent and 43.7 to 59.7 in different horizons. The higher bulk density $(1.53 \mathrm{Mg}$ m-3) was recorded in pedon $\mathrm{P}_{4}$ and lowest $\left(1.27 \mathrm{Mg} \mathrm{m}^{-3}\right)$ in pedon of $\mathrm{P}_{6}$ and increased with soil depth. The hydraulic conductivity ranged from 0.20 to $5.30 \mathrm{~cm} \mathrm{hr}^{-1}$ being lowest in last horizon of P4 owing to higher exchangeable $\mathrm{Mg}$.

Soil $\mathrm{pH}$ varied from 7.40 to 8.60 and increase in $\mathrm{pH}$ with depth might be due to leaching of bases from surface layer. Electrical conductivity varied from 0.17 to $2.0 \mathrm{~d} \mathrm{Sm}^{-1}$ (Table 2) in different horizons of pedons. Cation Exchange Capacity ranged from 33.30 to 67.10 $\mathrm{cmol}\left(\mathrm{p}^{+}\right) \mathrm{kg}^{-1}$ and it showed close relationship with clay and in particular smectitic clay. (Pal and Deshpande 1987; Gaikwad et al. 2020). The calcium carbonate content varied from 3.5 to 19.0 per cent. Higher calcium carbonate affects the physico-chemical characteristics of soil and may prevent root penetration (Sys 1985). Soil organic carbon and total carbon content ranged from 1.95 to 9.94 and 10.05 to $26.89 \mathrm{~g} \mathrm{~kg}^{-1}$, respectively in different horizons of pedons and in general, soil organic carbon decreased with depth but total carbon content increased with depth.

\section{Nutrient status of soils}

The available N, P and $\mathrm{K}$ ranged from 37.6 to $334.8,1.0$ to 27.1 and 224.9 to $583.8 \mathrm{~kg} \mathrm{ha}^{-1}$, respectively in different horizons of pedons and in general, their content decreased with the soil depth (Table 2). The variation in available $\mathrm{N}$ content in soil could be attributed to the differences in landforms intensity of cropping and agro-managements, losses through leaching denitrification etc. The results are in agreement with the findings of Malewar et al. (1998). The available $\mathrm{N}$ was optimum in Ap horizons of $\mathrm{P}_{1}, \mathrm{P}_{4}$ and $\mathrm{P}_{6}$, low in $\mathrm{P}_{9}$ and deficient in other pedons $\mathrm{P}_{2}, \mathrm{P}_{3}, \mathrm{P}_{5}, \mathrm{P}_{7}$ and $\mathrm{P}_{8}$. Available $\mathrm{P}$ was optimum in surface horizon of $\mathrm{P}_{6}$ and low to deficient in other pedons while $\mathrm{K}$ was above to optimum in $\mathrm{P}_{6}$ and $\mathrm{P}_{8}, \mathrm{P}_{4}, \mathrm{P}_{5 ;}$ optimum in $\mathrm{P}_{7}$ and low in $\mathrm{P}_{1}$.

The DTPA-Zn in different soils varied from 0.26 to $1.39 \mathrm{mg} \mathrm{kg}^{-1}$ against the critical level of $\mathrm{Zn} 0.6 \mathrm{mg} \mathrm{kg}^{-1}$ which, was also reported by Malode and Patil (2014). DTPA-Fe range from 2.20 to $7.11 \mathrm{mg} \mathrm{kg}^{-1}$ (Table 3) and found medium to higher, wherein DTPA-Mn varied from 2.34 to $21.89 \mathrm{mg} \mathrm{kg}^{-1}$ in all the soils. DTPA-Cu of the soil ranged from 1.57 to $4.51 \mathrm{mg} \mathrm{kg}^{-1}$ and decreased with depth. Soil $\mathrm{pH}$ is the most important factor regulating the Zn supply in calcareous soils.

\section{Conclusion}

The soils were slightly to moderately alkaline, low to moderate in organic carbon content and calcareous in nature. The soils were deficient in DTPA-Zn while $\mathrm{CaCO}_{3}$ induced chlorosis in calcareous soils may be 


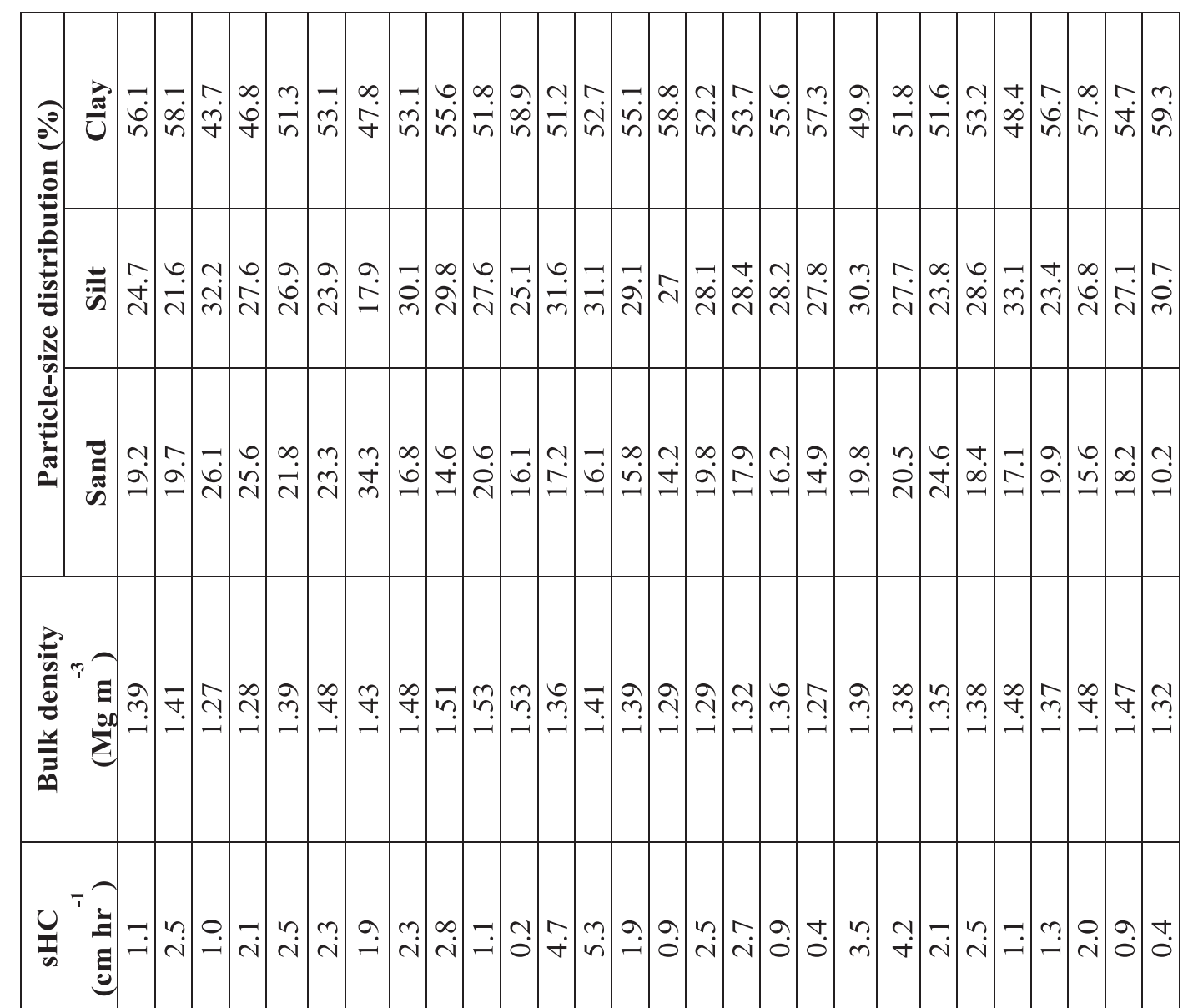

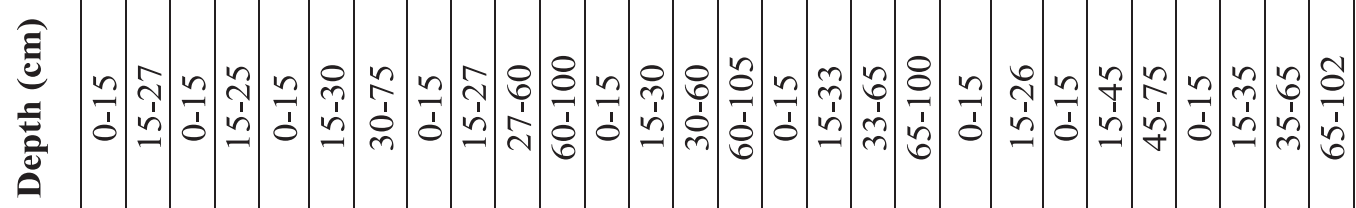

\begin{tabular}{|c|c|c|c|c|c|c|c|c|c|}
\hline 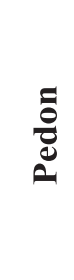 & $\begin{array}{l}\stackrel{\widehat{\vec{\theta}}}{2} \\
\underline{a}\end{array}$ & 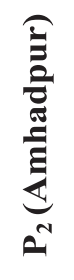 & 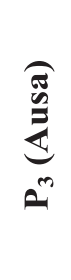 & 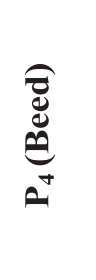 & 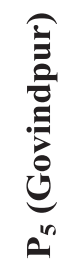 & 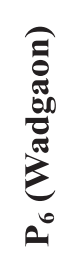 & 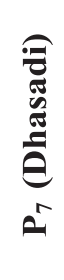 & 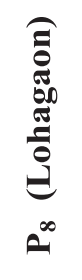 & 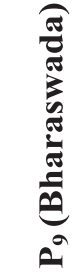 \\
\hline 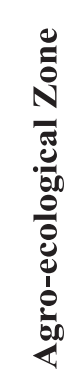 & & & & 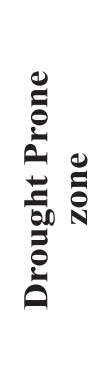 & & & & 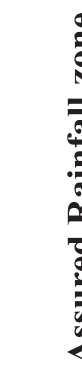 & \\
\hline
\end{tabular}




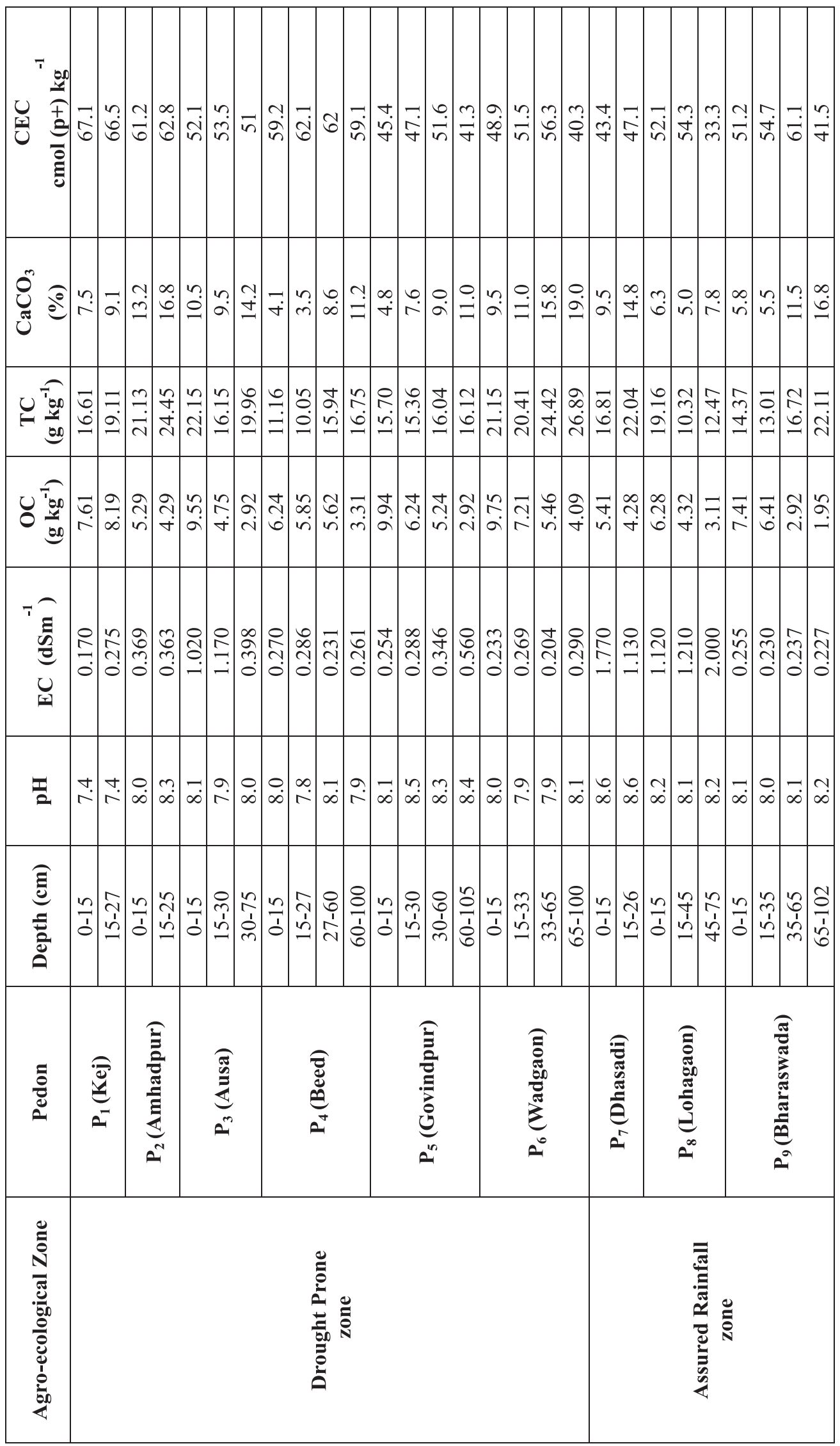




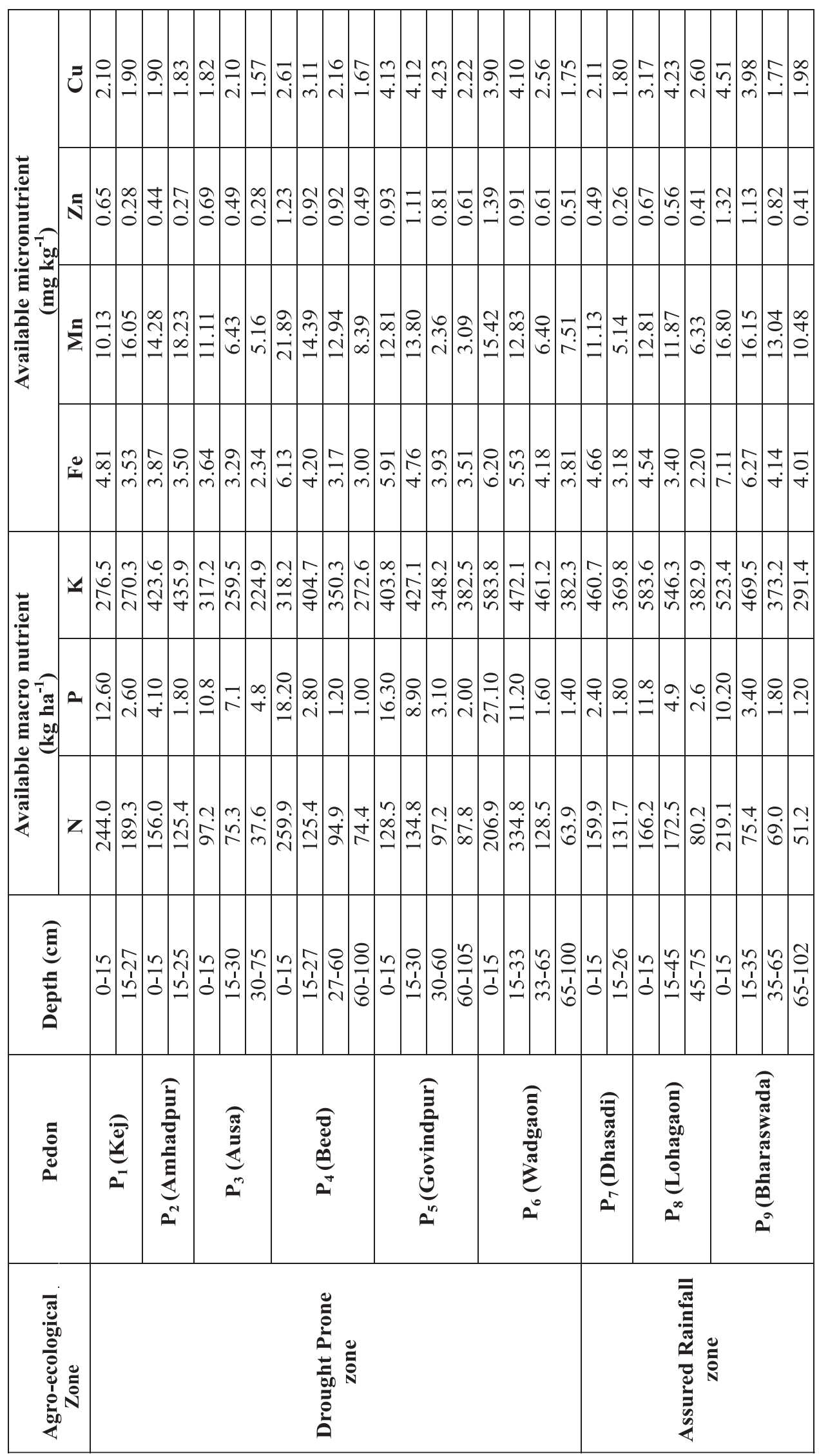


supplemented with Fe through foliar spray. Soil test based fertilizer application through inorganic / organic sources are advocated.

\section{References}

Anonymous. (2001). Technical manual U.S.E.P.A. (2001). Methods for collection, storage and manipulation of sediments for chemical and toxicological analyses: Technical manual U.S. Environmental Protection Agency Washington, D.C. 20460.

Black, C.A., Evans, D.D., Ensminger, L.E., White, J.L. and Clark, F.E. (1965). Methods of soil analysis Part-I, American Society of Agronomy. Inc. Publisher Madison, Wisconsin, USA.1968.

Gaikwad, S.S., Prasad, Jagdish, Ray, S.K. and Srivastava, R. (2020). Characteristics, mineralogy and spectral properties of some typical Vertisols of Vidarbha, Maharashtra, India. Journal of the Indian Society of Soil Science 68, 367-384

Hajare, T.N., Prasad, Jagdish and Gaikawad, S.T. (1995). Managing higher productivity of soybean through different agro-managements in Central India. Fertiliser News 40, 11-15.

Jackson, M.L. (1973). Soil Chemical Analysis, Prentice Hall of India Pvt. Ltd., New Delhi 27,117-119.

Karthikeyan, K., Puspanjali and Prasad, Jagdish (2014). Soil fertility status of some selected soybean (Glycine $\max$ L.)- growing soils of Malwa plateau, India. Journal of the Indian Society of Soil Science 62, 174-178.
Lindsay, W.L. and Norvell, W.A. (1978). Development of DTPA soil tests for zinc, iron, manganese and copper. Soil Science Society of American Journal 42, 421-428.

Malewar, G.U., Sayed, I. and Rudraksha, G.B. (1998). Integrated nitrogen management in Chilli (Capsicum annum L.) bulletin. Indian Institute Soil Science 2,156-163.

Malode, K.R. and Patil, V.D. (2014). Characterization of some Vertisols of drought prone zone of Marathwada region. Asian Journal Soil Science 9,137-141.

Olsen, S.R., Chole, C.V., Watanbe, F.S. and Dean, L.A. (1954). Estimation of available phosphorus in soil by extraction with $\mathrm{NaHCO}_{3}$, USDA Circular 939. US Washington.

Pal, D.K. and Deshpande, S.B. (1987). Characteristics and genesis of minerals in some benchmark Vertisols of India. Pedology 37, 259-275.

Prasad, Jagdish and Bradley, I. (1997). A computer model for assessing the suitability of soils for growing soybean (Glycine max) in Central India. Fertiliser News 42, 43-49.

Subbiah, B.V. and Asija, G.L. (1956). A rapid procedure for the estimation of available nitrogen in soils. Current Science 25, 259-260.

Sys, C. (1985). Land Evaluation Part I, II, III State University Ghent Publ., Belgium, pp 274.

Walkley, A. and Black, A.I. (1934). An examination of degtijare FF method for determining soil organic matter and a propose modification of chromic acid titration method. Soil Science 37, 29-38.

Received: August, 2020 Accepted: December, 2020 